Journal of Education and Teaching Learning (JETL)

Volume 4, Issue 1, January 2022

Journal Homepage:

http://pusdikra-publishing.com/index.php/jetl

\title{
The Effect Of Predict-Observe-Explain (POE) Learning Model On Students' Science Process Skills Biology In MTs Aisyiyah Binjai
}

\author{
Indayana Febriani Tanjung1, Khairuddin ${ }^{2}$, Ismayanti ${ }^{3}$ \\ 1,2,3Universitas Islam Negeri Sumatera Utara
}

Corresponding Author : indayanafebriani@uinsu.ac.id

ARTICLE INFO
Article history:
Received
20 February 2022
Revised
24 February 2022
Accepted
26 February 2022

Key Word

How to cite

Doi

\section{ABSTRACT}

This study aims to determine the effect of the Predict-Observe-Explain (POE) learning model on science process skills in biology learning. This research was conducted at MTs Aisyiyah Binjai in the academic year 2020/2021, and this research was conducted at the end of May to June 2021. The type of research carried out was descriptive quantitative research. In sampling the researchers took two classes, namely the experimental class with 32 students using the PredictObserve-Explain (POE) learning model and the control class with 32 students. The research method was carried out by preparing research instruments, namely observation sheets and student worksheets, validating instruments with 2 validators, namely North Sumatra State Islamic University lecturers and data collection was carried out by direct observation using observation sheet guidelines to see students' science process skills. The population in this study were all biology students of class VIII MTs Aisyiyah Binjai. Based on the research conducted, it shows the influence of students' science process skills using the Predict-Observe-Explain (POE) learning model. Judging from the results of data processing science process skills students in the experimental class with a percentage of $74 \%$ while in the control class with a percentage of only $41 \%$. So that the KPS value of students in the experimental class is higher than the control class.

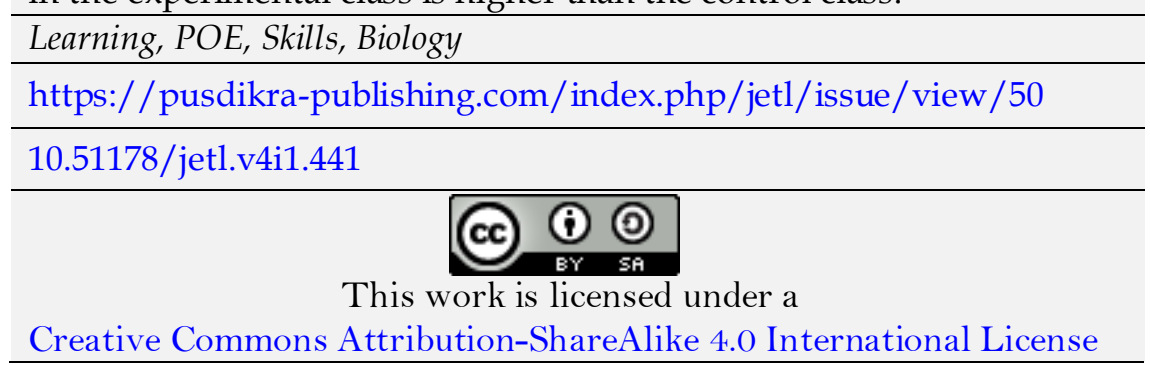

\section{PENDAHULUAN}

Belajar adalah suatu tahapan perubahan tingkah laku individu yang dinamis sebagai hasil pengalaman dan interaksi dengan lingkungan yang melibatkan unsur kognitif, afektif dan psikomotorik. Dengan kata lain, belajar adalah suatu proses dimana kemampuan sikap, pengetahuan dan konsep dapat dipahami, diterapkan dan digunakan untuk dikembangkan dan diperluas (Djamarah \& Zain, 2013).

Model pembelajaran POE (Predict-Observe-Explain) merupakan suatu cara efektif untuk membuat variasi suasana pembelajaran di kelas. Model 
pembelajaran POE ini dapat digunakan untuk menemukan ide siswa, dapat juga menyediakan informasi bagi guru untuk mengetahui cara berpikir siswa, memicu terjadinya kegiatan diskusi, memotivasi siswa untuk mengeksplor pengetahuan konsepsi siswa, memicu siswa untuk melakukan investigasi sehingga dapat memberikan pemahaman konsep peserta didik (Hidayah \& Yuberti, 2018). Model POE (Predict-Obiserve-Explain) memberikan kesempatan bagi siswa untuk menghasilkan pengetahuan konseptual mereka sendiri melalui rekonsiliasi dan negosiasi antara pengetahuan awal dan pengetahuan baru (Muna, 2017).

Model POE terdiri dari tiga tahapan dalam proses pembelajarannya yaitu predict (memprediksi), observe (mengamati) dan explain (menjelaskan). Dalam tahap predict yaitu membuat dugaan terhadap suatu peristiwa. Setelah suatu persoalan disajikan biasanya melalui demonstrasi. Demonstrasi akan membuat pelajar sains bersemangat dan lebih memperkaya pengetahuan tentang konsep dasar. Pada tahap observe yaitu Dugaan yang diberikan siswa dengan alasan yang diberikan harus dibuktikan dengan mempraktikkannya, melihatnya dalam kenyataan seperti melakukan pengamatan untuk membuktikan apakah prediksi yang diberikan benar atau tidak. Dan tahap explain yaitu ketika dugaan siswa ternyata terjadi dalam hasil pengamatannya. Jika hal ini terjadi siswa semakin yakin akan konsepnya. Siswa setelah itu merangkum apa yang ditemukannya kemudian menguraikan atau menjelaskan dengan lebih lengkap melaui komunikasi (Muslihah, 2014).

Dengan model pembelajaran POE terdapat perbedaan keterampilan proses sains siswa dengan model pembelajaran lainnya (Rosnaeni et al., 2018). Hasil penelitian juga menunjukkan bahwa (1) terdapat perbedaan yang signifikan keterampilan proses sains siswa kelas eksperimen dan kelas kontrol (2) terdapat perbedaan sikap ilmiah siswa kelas eksperimen dan kelas kontrol yang signifikan (3) terdapat perbedaan kemampuan kognitif yang signifikan antara siswa di kelas eksperimen dan kelas kontrol (Gultom, 2018).

Berdasarkan hasil observasi di MTs Aisyiyah Binjai pada keterampilan proses sains, khususnya pada mata pelajaran biologi siswa kelas VIII rata-rata masih belum sepenuhnya berjalan dengan baik saat proses pembelajaran yang sedang berlangsung, sehingga ketika diajak untuk mengamati (termasuk memberikan pendapatnya) kurang bersemangat. Dan demikian permasalahan tersebut akan berakar pada indikator selanjutnya yaitu memprediksi suatu dugaan yang telah diberikan oleh guru. Sehingga pada saat mengaplikasikan konsep dan melaksanakan suatu pengamatan siswa merasa kesulitan dan ketika terjadi kekeliruan konsep materi saat mengkomunikasikan hasil penemuannya di depan kelas. Hal ini dikarenakan guru masih menerapkan 
metode konvensional, yaitu sistem hafalan dan ceramah ketika proses pembelajaran berlangsung, sehingga siswa belum sepenuhnya mencapai keterampilan proses sains yang optimal. Permasalahan ini dapat diatasi dengan penerapan pembelajaran inovatif. Pembelajaran inovatif merupakan pembelajaran yang mampu menarik perhatian siswa dan melibatkan keaktifan siswa. Untuk itu penelitian ini membahas tentang model pembelajaran POE (Predict-Obiserve-Explain) terhadap keterampilan proses sains siswa biologi di MTs Aisyiyah Binjai.

\section{METODE PENELITIAN}

Penelitian ini dilakukan di MTs Aisyiyah Binjai. Waktu Penelitian dilaksanakan pada semester genap Tahun Ajaran 2020/2021. Penelitian dilakukan pada akhir bulan Mei sampai bulan Juni tahun 2021.

Jenis penelitian yang dilakukan dalam penelitian ini adalah jenis penelitian kuantitatif deskriptif. Penelitian kuantitatif adalah penelitian yang penyajian data-datanya berupa angka-angka, yang memiliki tujuan untuk menunjukkan hubungan antara variabel terikat dan variabel bebas, menguji teori, dan mencari generalisasi yang mempunyai nilai prediksi. Peneliti mengkelompokkan menjadi dua kelas yaitu kelas ekperimen dan kontrol. Kelas eksperimen adalah kelas yang memakai model pembelajaran POE dan kelas kontrol yaitu kelas yang tidak menggunakan model POE, melainkan dengan memakai model konvensional(Muslihah, 2014; Sugiyono, 2020).

Populasi merupakan objek yang akan menjadi sasaran dalam penelitian. Populasi dalam penelitian ini adalah seluruh siswa kelas VIII MTs Aisyiyah Binjai yang berjumlah tiga kelas, yaitu kelas VIII-A, VIII-B, dan VIII-C dengan jumlah siswa 95 orang.

\section{Tabel 1.}

Populasi Penelitian

\begin{tabular}{|c|c|c|c|}
\hline \multicolumn{3}{|c|}{ Kelas VIII } & Jumlah \\
\hline VIII-A & VIII-B & VIII-C & 95 \\
\hline 31 & 32 & 32 & \\
\hline
\end{tabular}

Sampel penelitian diambil dua kelas, satu kelas untuk kelas kontrol (tanpa memakai model pembelajaran POE), yaitu kelas VIII B dan satu kelas untuk kelas eksperimen (memakai model pembelajaran POE), yaitu kelas VIII A. Pengambilan sampel dilakukan dengan cara simple random sampling yaitu dengan mengundi nama-nama subjek dalam populasi yang memenuhi karakteristik. 
Proses pengumpulan data utama dalam penelitian ini dilakukan pada saat proses pembelajaran berlangsung. Pengambilan data dilakukan oleh tiga observer untuk mengamati aspek-aspek yang terdapat di dalam lembar observasi pada kelas eksperimen dan kelas kontrol untuk mengetahui ada tidaknya pengaruh keterampilan proses sains pada siswa. Hasil analisis data yang diperoleh dari hasil observasi merupakan data utama yang digunakan dalam penelitian ini. Kemudian menarik kesimpulan berdasarkan hasil analisis dalam lembar observasi.

\section{Tabel 2.}

Kriteria Penilaian KPS Keseluruhan Siswa

\begin{tabular}{|c|c|}
\hline Persentase & Kriteria \\
\hline $81 \%-100 \%$ & Sangat Baik \\
\hline $61 \%-80 \%$ & Baik \\
\hline $41 \%-60 \%$ & Cukup \\
\hline $21 \%-40 \%$ & Kurang \\
\hline $0 \%-20 \%$ & Sangat Kurang \\
\hline
\end{tabular}

\section{HASIL PENELITIAN DAN PEMBAHASAN}

\section{Hasil Penelitian}

\section{Hasil Pengamatan Keterampilan Proses Sains Siswa}

Tabel 3.

Rekapitulasi Nilai Keterampilan Proses Sains Siswa pada Kelas Eksperimen dan Kelas Kontrol

\begin{tabular}{|l|l|l|l|l|l|}
\hline \multirow{2}{*}{$\begin{array}{l}\text { Nilai } \\
\text { Siswa }\end{array}$} & \multirow{2}{*}{ Kategori } & \multicolumn{4}{|l|}{ Jumlah Siswa } \\
\cline { 3 - 6 } & & Eksperimen & $\%$ & Kontrol & $\%$ \\
\hline $19-24$ & Sangat Baik & 12 & $37,5 \%$ & 0 & $0 \%$ \\
\hline $15-18$ & Baik & 17 & $53,1 \%$ & 2 & $6,2 \%$ \\
\hline $11-14$ & Cukup & 3 & $9,4 \%$ & 7 & $22 \%$ \\
\hline $6-10$ & Kurang & 0 & $0 \%$ & 23 & $72 \%$ \\
\hline Jumlah & 32 & $100 \%$ & 32 & $100 \%$ \\
\hline Total KPS Keseluruhan & $74,4 \%$ & & $41,3 \%$ & \\
\hline
\end{tabular}

Pada tabel di atas peneliti memaparkan hasil kelas ekperimen dengan kategori "Sangat Baik" diperoleh 12 kode siswa. Sedangkan pada kelas kontrol tidak memperoleh satu siswa manapun yaitu dengan persentase $0 \%$. Kategori "Baik" pada kelas eksperimen diperoleh 17 siswa dengan persentase $53,1 \%$;sedangkan pada kelas kontrol diperoleh hanya 2 siswa dengan 
persentase 6,2\%. Kemudian kategori "Cukup" pada kelas eksperimen diperoleh 3 siswa dengan persentase 9,4\%; sedangkan pada kelas control diperoleh 7 siswa dengan persentase 22\%. Dilanjutkan dengan kategori "Kurang" kelas eksperimen tidak memperoleh siswa maka persentase menjadi $0 \%$; sedangkan pada kelas kontrol memperoleh sebanyak 23 siswa dengan persentase $72 \%$.

Oleh karena itu total keterampilan proses sains pada kelas eksperimen diperoleh secara keseluruhan sebesar $74,4 \%$ sedangkan pada kelas kontrol diperoleh hanya sebesar $41,3 \%$. Jika diselisihkan, antara kelas eksperimen dan kelas kontrol diperoleh persentase sebesar 35,1\% dari masing-masing kelas yang memilki jumlah siswa yang sama, yaitu 32 siswa. Berikut diagram yang menunjukkan persentase KPS siswa pada kelas eksperimen dan kontrol.

Gambar 1.

Persentase Keterampilan Proses Sains Siswa pada

Kelas Eksperimen dan Kontrol

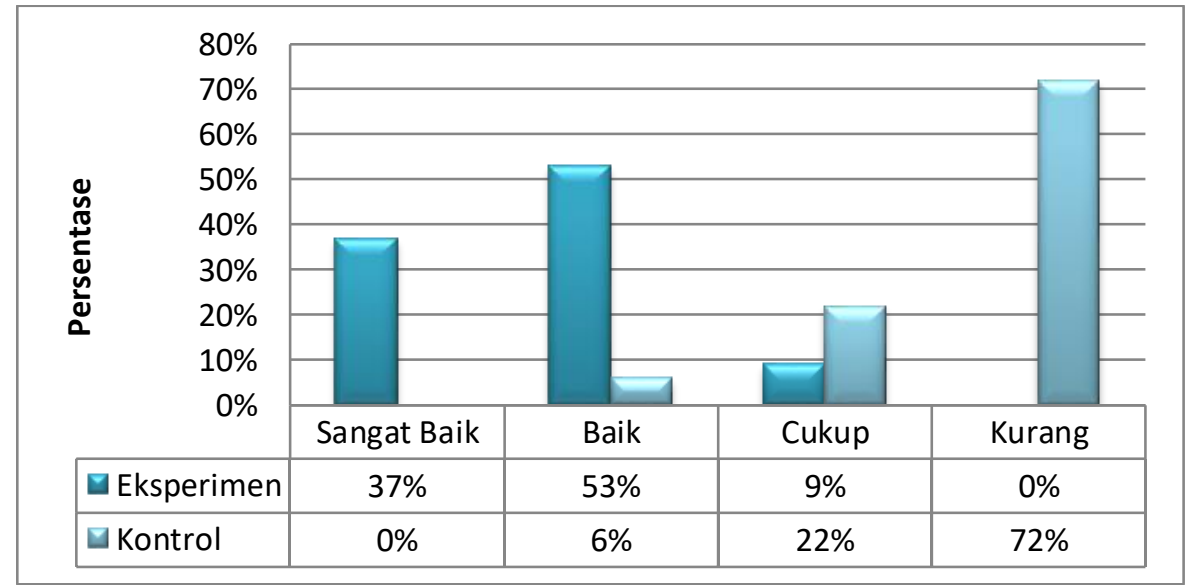

Lalu peneliti memaparkan persentase pada setiap 6 aspek KPS, yaitu mengobservasi, memprediksi, merencanakan penelitian, menginterpretasikan data, mengkomunikasikan hasil penemuan dan mengaplikasikan konsep pada kelas eksperimen dan kelas kontrol dalam bentuk tabel sebagai berikut:

Tabel 4.

Persentase Keterampilan Proses Sains Siswa pada

Setiap Aspek Kelas Eksperimen dan Kontrol

\begin{tabular}{|c|c|c|c|}
\hline No & Kelas & Kategori & Persentase \\
\hline 1 & Eksperimen & Mengobservasi & $14,5 \%$ \\
\cline { 3 - 4 } & & Memprediksi & $12 \%$ \\
\cline { 3 - 4 } & & Merencanakan Penelitian & $12,3 \%$ \\
\cline { 3 - 4 } & & Menginterpretasi Data & $13 \%$ \\
\cline { 3 - 4 } & & Mengkomunikasikan Hasil & $13 \%$ \\
& & Penemuan & \\
\hline
\end{tabular}


Journal of Education and Teaching Learning (JETL)

Volume 4, Issue 1, January 2022

Page 25-37

\begin{tabular}{|c|c|c|c|}
\hline & & Mengaplikasikan Konsep & $10 \%$ \\
\hline 2 & Kontrol & Mengobservasi & $7,2 \%$ \\
\cline { 3 - 4 } & Memprediksi & $8,1 \%$ \\
\cline { 3 - 4 } & Merencanakan Penelitian & $8,2 \%$ \\
\cline { 3 - 4 } & Menginterpretasi Data & $7 \%$ \\
\cline { 3 - 4 } & $\begin{array}{c}\text { Mengkomunikasikan Hasil } \\
\text { Penemuan }\end{array}$ & $6,1 \%$ \\
\cline { 3 - 4 } & Mengaplikasikan Konsep & $5,1 \%$ \\
\hline
\end{tabular}

Tabel diatas merupakan persentase keterampilan proses sains siswa pada Setiap kategori. Pada kelas eksperimen aspek penilaian "Mengobservasi" diperoleh 14,5\% secara keseluruhan, sedangkan pada kelas kontrol diperoleh $7,2 \%$. Pada aspek "Memprediksi" kelas eksperimen memperoleh persentase $12 \%$ sedangkan pada kelas kontrol memperoleh 8,1\%. Pada aspek "Merencanakan Penelitian" kelas eksperimen memperoleh persentase sebanyak $12,3 \%$ sedangkan kelas kontrol hanya 8,1\%. Kemudian pada aspek "Mengiterpretasikan Data" kelas eksperimen memperoleh persentase sebanyak $13 \%$ sedangkan pada kelas kontrol hanya memperoleh persentase sebanyak $7 \%$. Pada aspek "Mengkomunikasikan Hasil Penemuan" kelas eksperimen memperoleh persentase sebanyak $13 \%$ sedangkan kelas kontrol hanya memperoleh persentase sebanyak 6,1\%. Dilanjutkan dengan aspek Mengaplikasikan konsep kelas eksperimen memperoleh persentase sebanyak $10 \%$ sedangkan untuk kelas kontrol sekitar 5,1\%. Hasil persentase pada setiap aspek dapat dilihat melalui diagram berikut ini:

Gambar 2.

Persentase Keterampilan Proses Sains Siswa pada

Setiap Kategori Di Kelas Eksperimen dan Kontrol

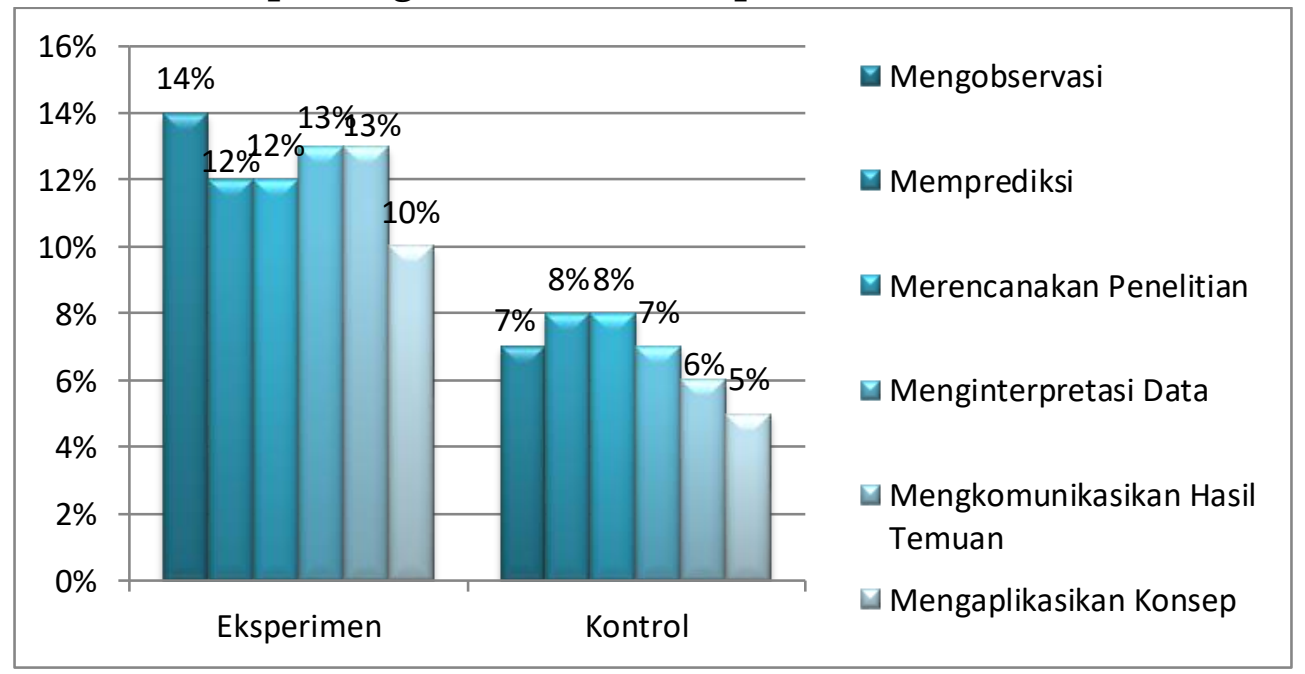




\section{Pembahasan}

Pada kelas eksperimen atau kelas yang memakai model pembelajaran predict obseve explain peneliti sebagai guru mengarahkan siswa untuk mempelajari materi sistem ekskresi manusia sebelum memasuki pertemuan pertama. Pada pertemuan awal guru masuk dengan mengucapkan salam, kemudian melakukan do'a bersama dan melakukan komunikasi sejenak kepada siswa sebelum memulai pelajaran. Kemudian guru memberikan apersepsi kepada siswa berupa tampilan video terkait materi sistem ekskresi. Pada tampilan video 1 guru menampilkan seseorang yang sedang buru-buru ke toilet karena sedang menahan untuk buang air kecil. Pada tampilan video 2 menampilkan seseorang yang sedang bersin. Pada video 3, guru menampilkan video tentang hati dalam menghancurkan sel darah merah yang sudah tua dan pada video 4 guru menampilkan seseorang yang berolahraga kemudian berkeringat. Kemudian guru membentuk setiap siswa menjadi 4 kelompok, yaitu kelompok ginjal sebagai kelompok 1, kelompok paru-paru sebagai kelompok 2, kelompok hati sebagai kelompok 3, dan kelompok kulit sebagai kelompok 4. Lalu masing-masing siswa diberikan LKPD oleh guru. kemudian guru mengarahkan siswa untuk mengerjakan soal yang tertera pada LKPD.

Pada kegiatan Predict (memprediksi) didapatkan oleh siswa setelah melihat video yang ditampilkan dari guru. siswa menuliskan prediksi mereka. Pada kegiatan Observe (Mengobservasi) siswa diarahkan kepada pengumpulan data dengan melihat literatur yaitu buku dan internet agar dapat mengetahui apakah prediksi siswa sudah benar atau atau belum, setelah itu hasil pengumpulan data di tulis pada LKPD. Pada kegiatan Explain (menjelaskan), siswa diminta menjelaskan prediksi dan hasil observasi ke depan kelas dalam diskusi, yaitu persentasi kelompok. Ketika semua kelompok telah melalui tahap Explain, siswa dapat membandingkan hasil persentasi mereka dengan kelompok lain, apakah di antara prediksi dan hasil observasi sudah relevan atau masih diluruskan konsepnya oleh guru kelas. Kemudian guru menyimpulkan seluruh kegiatan pembelajaran pada pertemuan ini. Pada pertemuan kedua guru menampilkan video kepada siswa yaitu gangguan atau kelainan pada sistem ekskresi manusia. Guru menjelaskan dengan singkat maksud dari gambar-gambar tersebut Kemudian guru membentuk kembali setiap siswa seperti kelompok yang sama seperti pertemuan sebelumnya, yaitu kelompok ginjal sebagai kelompok 1, kelompok paru-paru sebagai kelompok 2, kelompok hati sebagai kelompok 3, dan kelompok kulit sebagai kelompok 4 . Lalu masing-masing siswa diberikan LKPD oleh guru. kemudian guru mengarahkan siswa untuk mengerjakan soal yang tertera pada LKPD. Pada kegiatan Observe (Mengobservasi) siswa diarahkan kepada pengumpulan data 
dengan melihat literatur yaitu buku dan internet agar dapat mengetahui apakah prediksi siswa sudah benar atau atau belum,. Pada kegiatan Explain (menjelaskan), siswa diminta menjelaskan prediksi dan hasil observasi ke depan kelas dalam diskusi, yaitu persentasi kelompok. Ketika semua kelompok telah melalui tahap Explain, siswa dapat membandingkan hasil persentasi mereka dengan kelompok lain, apakah di antara prediksi dan hasil observasi sudah relevan atau masih diluruskan konsepnya oleh guru kelas. Kemudian guru menyimpulkan seluruh kegiatan pembelajaran.

Kegiatan memprediksi, mengamati, dan menjelaskan (mempresentasikan) mendorong keaktifan siswa selama pembelajaran berlangsung. Ini terjadi karena kegiatan pembelajaran yang menggunakan model POE sangat sesuai dengan karakteristik siswa MTs. Hal ini terbukti dengan data keterampilan proses sains siswa kelas eksperimen yang menunjukkan persentase sebesar $74,4 \%$. Persentase keterampilan proses sains siswa dalam pembelajaran kelas eksperimen masuk ke dalam kategori "Baik". Model POE terbukti dapat meningkatkan keterampilan proses sains siswa.

Pada aspek mengobservasi, didapatkan data oleh observer ketika siswa mengamati dengan seksama tampilan video yang menampilkan keempat reaksi organ ekskresi manusia. Pada video ginjal siswa dimunculkan rasa ingin tahu mereka untuk bertanya mengapa pada diri manusia terjadi peristiwa membuang air kecil dan apakah zat urin yang dikeluarkan benar-benar tidak dapat diperlukan lagi oleh tubuh. Kemudian pada video kedua menampilkan seseorang yang sedang bersin, siswa akan bertanya bagaimana bersin itu dapat terjadi,organ apa yang berperan penting dalam proses terjadinya bersin. Kemudian pada video ketiga siswa mengamati proses hati dalam menghancurkan sel darah merah yang tidak diperlukan lagi. Siswa dimunculkan pertanyaan mengapa sel darah merah yang tidak diperlukan lagi harus dihancurkan. Pada video keempat siswa menemukan seseorang yang sedang berolahraga kemudian berkeringat. Dan muncul lah pertanyaan dari mana keringat tersebut muncul atau keluar dari tubuh manusia. Pada aspek mengobservasi ini merupakan tahap apersepsi yang dapat memunculkan rasa ingin tahu siswa dengan melakukan pengamatan. Hal ini berkaitan dengan teori Piagett, yang mengemukakan bahwa keterampilan proses sains anak akan berkembang apabila dikomunikasikan secara jelas dan cermat yang dapat disajikan berupa grafik, diagram, tabel, gambar atau bahasa isyarat yang lainnya. Sehingga persentase kategori yang diperoleh pada kelas eksperimen sebanyak $14,5 \%$.

Pada aspek memprediksi peneliti memaparkan bahwa siswa yang telah melakukan pengamatan kemudian diarahkan untuk mengembangkan prediksi 
mereka, yaitu pengetahuan awal siswa. Observer menemukan bahwa sebagian kecil siswa mampu mengembangkan prediksi mereka dan masih sangat sederhana. Peristiwa ini berkaitan dengan teori keterampilan proses sains dasar siswa oleh Depdiknas yaitu "Memprediksi yaitu menduga sesuatu yang akan terjadi berdasarkan pola-pola peristiwa atau fakta yang sudah terjadi. Sehingga persentase kategori yang diperoleh pada kelas eksperimen sebanyak $12 \%$.

Pada aspek merencanakan penelitian siswa sebagian besar sudah mampu merencanakan bersama teman kelompoknya dengan cukup baik dengan kegiatan penyelidikan yang mencakup beberapa keterampilan proses sains seperti membuat pertanyaan, merumuskan pendapat awal mereka, mengumpulkan data dan menganalisis data dan membuat kesimpulan dengan literatur yang memadai dan bantuan LKPD yang teratur. Sehingga persentase kategori yang diperoleh pada kelas eksperimen sebanyak 12,3\%.

Pada aspek menginterprestasi data, siswa sebagian besar sudah banyak mengetahui cara mendapatkan data yang sesungguhnya melalui literatur yang telah disajikan dengan memilih literatur-literatur yang terpercaya, seperti artikel dan buku pelajaran IPA. Dan siswa juga sudah memahami makna data yang mereka peroleh dan mendapatkan pengetahuan baru mereka serta mampu membedakan prediksi awal mereka dengan hasil penelitian mereka. Sehingga persentase kategori yang diperoleh pada kelas eksperimen sebanyak $13 \%$.

Pada aspek mengkomunikasikan hasil penelitian sebagian kelompok siswa memilki kepercayaan diri maju ke depan kelas untuk mempresentasikan hasil LKPD mereka sesuai dengan pertanyaan LKPD yang tersedia. Sedangkan sebagian kelompok lain masih menunjukkan sikap pasif untuk mempresentasikan hasil kerja mereka. Karena mengkomunikasikan adalah kegiatan menyampaikan data yang diperoleh dari fakta-fakta yang ditemukan, konsep maupun prinsip ilmu pengetahuan menggunakan berbagai bentuk seperti laporan tertulis, audio, visual dan audiovisual. Sehingga persentase kategori yang diperoleh pada kelas eksperimen sebanyak $13 \%$.

Pada kegiatan mengaplikasikan konsep sebagian besar siswa didapatkan masih mengalami miskonsepsi dan masih perlu arahan dari guru agar konsep yang telah ditemukan tidak keliru. Hanya beberapa siswa memiliki prediksi yang cukup berkaitan dengan hasil penyelidikan mereka dengan dapat menyimpulkan antara prediksi dengan hasil kerja mereka dalam materi sistem ekskresi. Sehingga persentase kategori yang diperoleh pada kelas eksperimen sebanyak $10 \%$.

Berbeda dengan kelas eksperimen, pembelajaran IPA pada kelas kontrol menggunakan model konvensional. Siswa mengikuti pembelajaran dengan 
aktivitas yang terbatas. Siswa lebih banyak mendengarkan penjelasan guru dan mencatat materi yang ditulis guru di papan tulis. Pembelajaran masih terpaku pada penyampaian materi dari guru kepada siswa karena memang didominasi oleh pemberian ceramah oleh guru. Seperti pendapat yang dikemukakan Asmani bahwa "Metode ceramah adalah sebuah metode pembelajaran yang sering digunakan oleh guru dengan cara menyampaikan informasi dan pengetahuan secara lisan kepada siswa yang pada umumnya mengikuti secara pasif". Guru masih mendominasi proses pembelajaran sehingga siswa cenderung pasif karena keterlibatan yang terbatas. Ini terbukti dari rata-rata nilai aktivitas belajar siswa kelas kontrol menunjukkan persentase sebesar $41,3 \%$.Walaupun persentase keterampilan proses sains siswa pada kelas kontrol masuk dalam kategori baik, angka tersebut lebih rendah dibandingkan dengan rata-rata nilai aktivitas belajar siswa pada kelas eksperimen.

Pada kegiatan mengobservasi, sebagian masih mampu mengamati gambar yang telah diberikan oleh guru walaupun masih sangat sederhana begitupun dalam memprediksi, namun sebagian besar masih belum memahami dan belum mengembangkan prediksi yang dimiliki karena tidak ditunjukkan oleh guru apersepsi yang dapat memunculkan rasa ingin tahu siswa. Pada kegiatan merencanakan penelitian, siswa sedikit merasa kurang bersemangat karena LKPD yang diberikan guru diarahkan khusus ke individu siswa tanpa melakukan diskusi kelompok. Pada saat menginterprestasikan data sebagian siswa sudah mampu memahami hasil pengumpulan data yang telah mereka cari di internet dan buku dan membandingkan dengan teman sebangkunya namun sebagian dari siswa masih sedikit kesulitan dalam memahami hasil temuan mereka. Pada kegiatan mengkomunikasikan hasil temuan siswa hanya menuliskan hasil data dalam bantuan LKPD saja tanpa adanya presentasi.kemudian pada kegiatan mengaplikasikan konsep ditemukan observer hanya sebatas pertanyaan-pertanyaan singkat yang dilemparkan guru hanya 2-3 orang saja yang percaya diri menjawab pertanyaan guru. Hal tersebut dikarenakan siswa yang belum bisa menyimpulkan hasil temuan mereka apakah sudah relevan atau belum. Aktivitas belajar siswa yang terbatas menjadi penyebab rendahnya hasil belajar yang dicapai oleh siswa karena kurangnya keterlibatan siswa secara aktif dalam pembelajaran. Siswa kurang memahami materi yang diberikan dan belum mencapai pembelajaran yang bermakna. Ini terbukti dari hasil belajar siswa pada kelas kontrol dengan nilai rata-rata kelas sebesar $41,3 \%$. Rata-rata nilai hasil belajar siswa pada kelas kontrol lebih rendah dibandingkan dengan kelas eksperimen. 
Dengan serangkaian kegiatan pembelajaran yang menggunakan model POE, siswa berlatih untuk melakukan penelitian sederhana yakni kegiatan memprediksi yang kemudian dibuktikan secara ilmiah melalui pengamatan. Pembelajaran yang melibatkan siswa secara langsung menciptakan pembelajaran yang bermakna sehingga materi mudah diterima oleh siswa. Model pembelajaran POE juga menumbuhkan sikap ilmiah dan melatih keterampilan proses sains siswa melalui pembelajaran IPA.

(Nuraeni et al., 2020) Pelaksanaan pembelajaran IPA dengan menerapkan model Predict, Observe, Explain (POE) dapat meningkatkan keaktifan siswa dalam kegiatan pembelajaran melalui tahapan memprediksi yang harus berangkat dari fenomena yang ada, tahapan mengamati siswa melakukan eksperimen langsung dan tahapan Dalam berkomunikasi siswa harus berdiskusi untuk membandingkan hasil dari proses observasi dengan prediksi yang telah dibuat. Penerapan model POE dapat meningkatkan keterampilan proses sains siswa. (Amal \& Kune, 2018) Model POE dapat meningkatkan hasil belajar dan proses pembelajaran. (Nurlaili, 2019) Model pembelajaran POE pada materi larutan elektrolit dan nonelektrolit berpengaruh terhadap keterampilan proses sains siswa. (Wardani \& Gayatri, 2018) Keterlaksanaan model Predict-Observer-Explain (POE) berada dalam kategori sangat baik, Ketrampilan proses sains siswa termasuk kedalam kategori baik dan Peningkatan penguasaan konsep siswa juga berada pada kategori baik.

Sehingga dapat dikatakan terdapat Pengaruh pada Keterampilan Proses Sains Siswa Biologi pada Kelas Eksperimen dan Kontrol di MTs Aisyiyah Binjai. Artinya model pembelajaran POE dapat meningkatkan keterampilan proses sains siswa.

\section{KESIMPULAN}

Hasil penelitian yang telah dilaksanakan di MTs Aisyiyah Binjai menunjukkan bahwa terdapat pengaruh model pembelajaran Predict Observe Explain terhadap keterampilan proses sains siswa biologi di MTs Aisyiyah Binjai. Dengan perolehan hasil data persentase pada setiap indikator keterampilan proses sains di kelas eksperimen lebih tinggi dari kelas kontrol. Hasil data observasi siswa secara keseluruhan pada kelas eksperimen mendapatkan persentase $74,4 \%$ dengan kategori "Baik". sedangkan kelas kontrol hanya memperoleh persentase sebanyak 41,3\% dengan kategori "Cukup". Jika dibandingkan terdapat perbedaan cukup jauh antara kelas eksperimen menggunakan model POE dengan kelas kontrol yang hanya menggunakan model kovensional saja. 


\section{PENGAKUAN}

Tulisan merupakan hasil riset penulis yang dilakukan di MTs Aisyiyah Binjai, ucapan terimakasih penulis haturkan kepada seluruh guru dan siswa yang ada di MTs Aisyiyah Binjai.

\section{DAFTAR PUSTAKA}

Amal, A., \& Kune, S. (2018). Peranan Pembelajaran Ipa Berorientasi POE (Predict, Observe, Explain) Untuk Meningkatkan Keterampilan Proses Dan Hasil Belajar Di Sekolah Dasar. Prosiding Seminar Nasional Pendidikan, 1(1). https://jurnal.umj.ac.id/index.php/SNP/article/view/2927

Djamarah, S. B., \& Zain, A. (2013). Strategi Belajar Mengajar. Rineka Cipta.

Gultom, E. C. (2018). Penerapan Model Pembelajaran Predict, Observe, Explain (POE) Pada Materi Larutan Elektrolit Dan Non Elektrolit Untuk Meningkatkan Keterampilan Proses Sains, Sikap Ilmiah Dan Kemampuan Kognitif Siswa. Quantum: Jurnal Inovasi Pendidikan Sains, 9(1). https:/ / doi.org/http:/ /dx.doi.org/10.20527/quantum.v9i1.4864

Hidayah, A., \& Yuberti, Y. (2018). Pengaruh Model Pembelajaran POE (PredictObserve-Explain) terhadap Keterampilan Proses Belajar Fisika Siswa Pokok Bahasan Suhu dan Kalor. Indonesian Journal of Science and Mathematics Education, 1(1). https:/ / doi.org/https:/ / doi.org/10.24042/ijsme.v1i1.2470

Muna, I. A. (2017). Model Pembelajaran POE (Predict-Observe-Explain) dalam Meningkatkan Pemahaman Konsep dan Keterampilan Proses IPA. ElWasathiya: Journal of Religious Studies, 5(1). http:/ / ejournal.kopertais4.or.id/mataraman/index.php/washatiya/article /view/3028

Muslihah, E. (2014). Metode dan Strategi Pembelajaran. Haja Mandiri.

Nuraeni, I., Djumhana, N., \& Saputri, A. E. (2020). Penerapan Model Predict Observe Explain (POE) Untuk Meningkatkan Keterampilan Proses Sains Siswa Kelas V Sekolah Dasar. Jurnal Pendidikan Guru Sekolah Dasar (JPGSD), 5(3). https:// doi.org/https://doi.org/10.17509/jpgsd.v5i3.30044

Nurlaili, N. (2019). Analisis Keterlaksanaan Model Pembelajaran Predict Observe Explain Pada Materi Larutan Elektrolit Dan Nonelektrolit Dan Pengaruhnya Terhadap Keterampilan Proses Sains Siswa. Journal of The Indonesian Society of Integrated Chemistry, 11(1), 28-37. https:/ / doi.org/10.22437/jisic.v11i1.6833

Rosnaeni, R., Muslimin, M., \& Saehana, S. (2018). Perbandingan Keterampilan Proses Sains Antara Kelompok Siswa yang Diajar Dengan Model POE (Predict-Observe-Explain) dan Model Discovery Pada Siswa Kelas X SMA Negeri 1 Sindue Tombusabora. Jurnal Pendidikan Fisika, 6(1). 
Page 25-37

https:// doi.org/http://dx.doi.org/10.24127/jpf.v6i1.1260

Sugiyono. (2020). Metode Penelitian Pendidikan. Alfabeta.

Wardani, A. A. K., \& Gayatri, Y. (2018). Penggunaan Model Pembelajaran

Predict-Observer-Explain (Poe) Untuk Meningkatkan Keterampilan Proses Sains Dan Penguasaan Konsep Siswa Pada Materi Ekosistem. Pedago Biologi: Jurnal Pendidikan Dan Pembelajaran Biologi, 6(2). https://doi.org/http://dx.doi.org/10.30651/jpb.v6i2.3916 